\title{
Canon Fodder and the Intimacy of Dialogues
}

\author{
Freeden Blume Oeur, Tufts University, USA
}

Forthcoming in Critical Sociology

\begin{abstract}
Michael Burawoy's essay, "Decolonizing Sociology: The Significance of W.E.B. Du Bois” (2021), forges dialogues between the scholar denied and established theorists with the aim of reconstructing the sociological canon. My commentary situates the author's essay and his own Du Boisian turn in a long career dedicated to reflexive science and recomposing theory. I reflect on the seemingly innocuous notion of a dialogue itself: its implications for sociological theory and practice, and how it supports decolonial efforts. Thinking with Toni Morrison, Hazel Carby, Lisa Lowe, and others, I offer a sketch of a decolonial methodology — what I call a Du Boisian shadowplay — that brings into view the intimate dimensions of imperialism. Ultimately, such a feminist methodology reconstructs dialogues that reflect on researcher standpoints and nested imperial histories; and in the face of today's social crises, nurtures dialogues that are animated by an ethic of love.
\end{abstract}

\section{Keywords}

W.E.B. Du Bois, sociological canon, decolonization, imperialism, dialogue, intimacy 


\section{Introduction}

A long overdue Du Boisian turn in Sociology has dovetailed with efforts to imagine a decolonial discipline. It is at this juncture we find Michael Burawoy’s essay, "Decolonizing Sociology: The Significance of W.E.B. Du Bois," based on an address given at the International Sociological Association in 2021. Building on a long career of defending the possibility of a transformative and critical sociology, Burawoy brings the discipline's essential ideas and questions to bear on today's social crises. For the author, the foundation must be rebuilt, but a sociological canon not abandoned altogether. As Burawoy (2021a:551) writes, "The research programs of Marx, Weber, Durkheim, and Du Bois are fortified and reconstructed through conversations with each other. Out of the conversations there tentatively emerge new criteria that become foundational to our discipline." What we might call a reformist view-even if Burawoy himself is not keen on the label ${ }^{1}$ — carves a third path between two opposing alternatives: a camp Burawoy himself identifies that encourages letting go of the idea of a canon (Connell, 1997; Itzigsohn and Brown, 2020) and a more conservative faction that would keep the canon intact and Du Bois and others outside its gates (Riley, 2021).

My commentary has three larger aims. My immediate impression was that there is something very Burawoyian about this essay. That is the author's abiding concern with reconstructing theory, which animates much of Burawoy's work but is perhaps most evident in his stewardship of the extended case method (1998), a methodology that uses anomalies in the social world to revise pre-existing theory. This association between theory and method clued me into something else, which is Burawoy's steadfast commitment to intellectual meetingsimagined conversations between theorists - that nurture a reflexive Sociology. I hope also to have my own productive dialogue with the author. Burawoy's essay pushed me to reflect 
carefully about my own relationship with theory, Du Bois, and decolonization, and for that I am grateful. To borrow a term that Burawoy (2019:192) has used elsewhere in another effort to nurture intellectual dialogue, I use the strategy of "absorption" here. My way of demonstrating a critical appreciation for the essay is to theorize and reconstruct what is hiding in plain sight: the idea of a dialogue itself.

Second, my commentary asks what exactly is decolonial regarding Burawoy's intentions. Reconstituting the canon through a dialogue with Du Bois is no guarantee of a decolonial Sociology. And Burawoy leaves us to infer for ourselves because, curiously, the word "decolonizing" appears just a single time in the article. Yet I suspect that Burawoy's idea of what makes a decolonial sociology is not unlike that of other writers (e.g., Meghji, 2021). I gather as much when Burawoy enumerates five ways that Du Bois challenges the traditional canon: to pursue a global and historical sociology that is attuned to colonialism, to be reflexive and utopian, and to be transdisciplinary and public-facing.

Third, my commentary considers what exactly is $D u$ Boisian about this effort. Burawoy mentions many Du Boises; building on Morris's (2015) impression of Du Bois as the "scholar denied," Burawoy takes the longer view of someone who evolved into the "scholar liberated" and spent his final days in Ghana. But Burawoy seems to me to be writing in the spirit of the scholar as the pragmatist Du Bois. Reforming the canon is in the spirit of the pragmatist scholar who sought a "meliorist" third path in his work between the most cynical possibility of historical statis and the most sanguine prospect that sweeping change was possible (Taylor, 2004). Pragmatically speaking, for Burawoy, even a decolonial Sociology must contend with existing theory if it hopes to transcend it altogether. 
I also invoke the pragmatist $\mathrm{Du}$ Bois as a matter of inquiry. I am motivated by the basic pragmatist goal of considering the value of old concepts in new contexts: to find what is most useful in a debate about Du Bois and the canon so we can just "get on with things" (Taylor, 2004:113). While the "decolonial Du Bois" is perhaps newer intellectual territory for Burawoy, the critic is very much thinking about Du Bois and decolonization through the prism of his own past writings. Taking, therefore, my own long view of Burawoy's scholarship, my intention here is not to evaluate whether maintaining some semblance of a canon achieves the goal of decolonization. Instead, I want to consider the seemingly innocuous idea of a dialogue and its implications for sociological theory and practice. This approach begs several questions. How exactly does a conversation achieve the goals of decolonization? What are the terms of this exchange? Who serves as translator? Who facilitates the exchange and serves as arbitrator when disagreements arise? If the imposition of master languages is itself a legacy of colonial violence, then what vocabularies are decolonial? And why is Burawoy motivated in this moment to take up the challenge of addressing these questions?

My own small contribution to this ongoing dialogue is to offer a sketch of a Du Boisian methodology that is in the spirit of Burawoy's intentions and that helps address these questions. Beyond the broad sense of an orientation to research and how a discipline conducts its affairs, my understanding of methodology builds on Itzigsohn and Brown's (2020) focus on Du Bois's self-reflective research practices linking the political and the personal. Du Bois embraced a method that adjudicates and translates competing visions of social reality, compulsively seeking to be aware of his own standpoints in these power relations and in the service of a specific kind of historical revision: one that "transforms historical narration into counter-propaganda capable of offering forward new "truths" about the past that might alter futures yet to come" (Weinbaum, 
2013:440). So, when Burawoy speaks of "reconstructing" the canon, his thinking is not far off from the Du Boisian method, executed forcefully in Black Reconstruction (1992[1935]), of correcting the false historical record of propaganda. Du Bois accomplishes this by engaging but then transcending Marxism. Following Lemert (2000:220), I see Du Bois's "reconstruction" and Burawoy's "recomposition" as a "deconstruction" in the Derridian sense: "as an attitude. It is a rewriting of the history of thought—and, by implication, of history itself—-by the trick of using the language of thought to turn thinking — and history—on their sides.”

If conversations are the stated terms, then I view my own role here as facilitating a dialogue between Burawoy and his interlocutors, or those who variously care about Du Bois, decolonization, and this stubborn thing we call the canon. Toni Morrison helps guide me in this work. In 1988, Morrison deconstructed the canon of American literature. ${ }^{2}$ She reflected on how the current anxieties over what to do with the canon were propelled by the "unspeakable" African American presence in white literature. Morrison (1988:135) will also quip that African American literature "remains the helpful doorman into the halls of sociology." (An insight that $\mathrm{Du}$ Bois embraced given his penchant for using fiction to convey social realities.) How prescient: thirty years later, gatekeepers (e.g., Riley, 2021) express their own anxieties and empty criticisms as the once unspeakable imperial legacies of Sociology have begun to surface. And I am struck by how Burawoy's view on the canon debates mirrors that of Morrison, who defended the idea of an enhanced canon that requires "neither slaughter nor reification" (Morrison, 1988:123). Du Bois, who endorsed a "radical democracy of talent" (Krell, 2000:112) in his writings, believed the same. Yet Morrison and Du Bois demand that we not lose sight of the structured absences behind an engagement with the foundational ideas on which we rely. Ironically, the 
"unspeakable" presence in Burawoy's essay is the dialogue itself, an intellectual practice with imperial vestiges, but one with a radical potential for connection and world-building.

Through this prism, Burawoy's past writings and this essay actually create room for a decolonial methodology that is more creative and insurgent than a series of dialogues with canonical thinkers. A method we might call a Du Boisian shadowplay urges us to consider three dialogues. First, Du Bois's lifelong practice of critical revision—of careful scrutiny of his own past work-illuminates the tradition of Du Bois meeting Du Bois. Beyond Morrison, I take inspiration from Tiffany Lethabo King, Katherine McKittrick, Hazel Carby, and Lisa Lowe, who urge thinking intimately about colonial histories. Their insights nurture insurgent methodologies with a feminist imprint. I am thinking of intimacy in terms of desire, but also as "connexions," in Lowe's (2015:19) words, or those "implied but less visible forms of alliance, affinity, and society among variously colonized peoples." Du Bois traced these intimate colonial relations through the language of water—darkwater, as he called it, or the shared blood and sweat of the "international laboring class of all colors" (Du Bois, 1999[1920]:56) —as well as shadows, which saturates Du Bois's writings and is the preferred analytic of my commentary. These relations are the structures of feeling that embed Du Bois's fictional writings, the literary formulations that reflect not only Du Bois's own personal attachments but speak into existence an “emergent collective consciousness" (Filmer, 2003:204).

Second, Burawoy's essay itself appears to me to be an instance of this critical revision in the spirit of Du Bois, so an instance of Burawoy meeting Burawoy. It is difficult to fully understand Burawoy's essay outside of the context of his own intellectual biography. Burawoy's understanding of a reflexive social science here not only embraces two overlapping dialogues (or axes) — between theory and data, and between observer and participant—but that these various 
dialogues prefigured for Burawoy his current double engagement between Du Bois and the canon, and between that reconstructed canon and decolonization. ${ }^{4}$ Yet, I wonder: what are the imperial intimacies that animate the author's decades-long commitment to dialogues? While sociology suffers from historical amnesia over its imperial legacies (Steinmetz, 2013), the corrective is not necessarily to highlight overlooked origin stories, or to speculate on how Sociology might be better off today had marginalized scholars received proper recognition in an earlier time. Instead, the method I stress here is a reconsideration of the essential decolonial notion of standpoints: greater transparency about how we as practitioners come to study and relate to our work; our biases and political commitments; and ultimately how decolonial dialogues ask us to consider how we relate to one another and the obligations that those relations entail.

Last, we have the dialogue between the author and the scholar denied, the instance of Burawoy meeting Du Bois, where for Burawoy, Du Bois evolves as the public sociologist par excellence to an architect for a decolonial sociology. I first imagined a dialogue between Burawoy and Du Bois while doing research for what would become my first book, an ethnographic, Du Boisian investigation of African American, all-boys schooling (Blume Oeur, 2018). I bring to the present conversation some insights I gleaned from that study. As I consider my own motivations for joining these decolonization conversations, I want to encourage us to think about these dialogues in terms of radical intimacy and connection beyond the mere task of theory reconstruction.

\section{A Dialogue on Dialogues}


Burawoy's essay is structured around conversations, or meetings, between Du Bois and canonical theorists. Now, who could dispute the need for more conversation? Scholars have found it productive to stage fictionalized encounters between Du Bois and his contemporaries. For instance, in light of their "intellectual contemporaneity," Fields (2002) imagines a whimsical conversation between Du Bois and Durkheim, and there is Kennedy's (2019:10) thoughtful work of "fusing horizons" between Du Bois and Antonina Kłoskowska. ${ }^{5}$ Given that Du Bois and Weber had actually known one another and briefly corresponded (McAuley, 2019), their relationship in particular has been an object of lore, nurturing speculation for what could have been. I want to stress the structures of feeling (Williams 1980) behind these "missed encounters" that call to mind the popular "missed connections" of personal ads. Anticolonial writers help create these intimate "connexions" (Lowe 2015) that swell with a sense of yearning and anticipation for new and unexplored intellectual vistas.

The notion of an encounter is also a relic of imperial epistemologies. Academic language - particularly when used to discuss the idea of progress — is burdened with allusions to colonialism and empire, from "charting new territory" to "charting new ground," to "mining" and "excavating" and "pioneering." I suspect Burawoy has "encounters" in mind because this is the language that he adopts in his recent book, Symbolic Violence: Conversations with Bourdieu (2019). The method I propose here acknowledges and resists the use of imperial grammars. It draws out from the colonial shadows those intimate encounters often overlooked in structural accounts of imperialism (Carby, 2021). I also find helpful the suggestion from Meghji (2021) (who takes a reformist view similar to Burawoy's) to embrace a "sociology in conversations." Meghji's (2021:96) inspiration is the Zapatista motto of caminando, preguntando, or "“walking while asking questions,' an epistemic ethic that transcends the Western commitment to 'walking 
while preaching."' Importantly, this tradition animates Indigenous feminist notions of relationality, where the construction of knowledge relies on collaboration, transparency, and humility; and where dialogues are imagined expansively to include testimonials and kin relations, real and imagined (Sãenz 2015).

\section{Du Bois Meets Du Bois}

In a 1904 review of his own book, The Souls of Black Folk, Du Bois describes provocatively a "penumbra of vagueness" surrounding the text (Andrews, 2007:157): a statement that is instructive reasons methodological and conceptual. For Du Bois, shadows are where method meets theory. First, Du Bois's self-review is a remarkable instance of a third consciousness, where the author turns a microscope on his own explication of double consciousness. This concern with self-citation and continual reflection and revision of his own writings are indicative of Du Bois's larger obligations to dialectical formalism (Edwards, 2009). I have previously referred to this Du Boisian practice as aftershadowing, a manner of recalibrating ideas and connections between texts across time, as a single text or piece of writing casts shadows that envelop, illuminate, and possibly even disguise ideas in later work. As Du Bois was self-consciously in dialogue with himself, he was able over many years to trace and rethink his own ties: professional, personal, and familial (Blume Oeur 2021).

In Du Bois's words, Black Americans live in the shadow of the racial veil, and shadows and their variants appear often in his writings. The penumbra refers to the outer edges of a shadow, where light is only partially obscured, unlike the umbra, the area of the shadow where no light enters. To think of this phrase of Du Bois's in the terms of the present conversation, the penumbra is the area in which darkness meets light, that which partially obscures and partially 
illuminates. As I see it, the aim of a Du Boisian shadowplay is not necessarily to "reveal" life in the shadow of the veil, but to consider the radical possibilities in the shadow's penumbral location, or "the interstices of the invisible and visible" (McKittrick, 2021:15, emphasis in the original).

In his 1925 essay "Worlds of Color," Du Bois explains how the "riddle of Europe" had cast "colonial shadows" around the globe. Du Bois understood that a multitude of color lines were nested in histories of global empire, and he was concerned with the degree of depth and opacity across these colonial shadows. Du Bois's essay, "Worlds of Color," published in Foreign Affairs, was bold and error prone in equal measure (Berman, 2000). While Du Bois's crosscomparative methodology revealed imperialism not to be monolithic, it also, for example, had its blind spots with respect to France. Du Bois even suggested that a French version of "Latin imperialism," born out of more amicable race relations, was more preferable to the "crass" version of British imperialism.

In the moment a scholar meets another scholar, Du Bois's lesson is that the scholar must also confront themselves. The tradition of sociologists from the metropole obscuring their own standpoints is itself an imperial legacy of the discipline. In an act of aftershadowing, Du Bois will reuse "Worlds of Color" as the title of the third book of his trilogy, The Black Flame, completed in the final decade of his life. A sprawling work of historical fiction as well as quasiautobiography, it follows a Black protagonist by the name of Manuel Mansart, whose racial consciousness expands to include a vision of global socialism and anticolonialism. ${ }^{6}$ Through the 1930s, as part of a larger effort to link the struggles of the "darker races of the world" and a more concerted effort to nurture a politics of Afro-Asian solidarity, Du Bois will regrettably elevate Japan as "the champion of the darker world" (Mullen, 2015:148). Coinciding with Du Bois's 
own busy period of travel that takes him from Europe to China and Japan, in the books Mansart himself tours the world in 1936. Mansart will write home: "The Japanese clan was an effective social organ and her art expression was unsurpassed. She might have led Asia and the world into a new era. But her headstrong leaders chose to apply Western imperialism to her domination of the East, and Western profit-making replaced Eastern idealism" (Du Bois, 2007[1961]:43). In the same passage, Mansart will include reflections that are at times near verbatim passages of $\mathrm{Du}$ Bois's own words from a March 1937 column in The Pittsburgh Courier, save for important instances of what amounts to a kind of retroactive and selective editorializing, where the fictional Mansart can see the absence of "democratic freedom" in Japan when Du Bois himself lacked that foresight in 1936. According to Mullen (2015), with these and other acts of textual revision, the older Du Bois harshly scrutinizes his younger self. ${ }^{7}$

If canonical American literature has found white authors playing out their racial fantasies in what Morrison (1993) has called a "playground for the imagination," then Du Bois turns to literature and journalism as vehicles of counterpropaganda. Mansart's grandson joins the cause of anti-imperial struggle in France. Another major character, Jean Du Bignon, travels to the West Indies and learns of the depth of French and British imperialism in that region, "born of the blood of Negro slaves" (Du Bois 2007[1957]:51). Writing from Ghana shortly before his death, Du Bois (1961) will link the French and American Revolutions in their shared aim of protecting slavery, and how each ushered in a dictatorship of plutocracy.

\section{Burawoy Meets Burawoy}

In Symbolic Violence, Burawoy dedicates a standalone chapter to him "meeting" Bourdieu. It is the culmination of an intellectual journey where Burawoy evolves from a 
Bourdieu-skeptic to being more critically appreciative of the French sociologist. I am curious with how the present essay is for Burawoy a similar exercise of aftershadowing. Those familiar with Burawoy's work will recognize that this brief article has the hallmarks of the author's intellectual and political commitments. The dominant theme is a belief in the transformative potential of sociology as a reflexive social science. There is a strong affinity between Burawoy and Du Bois, where the former finds in the latter an intellectual who can challenge the sociological canon by encouraging "A reflexive science that places social scientists within the world they study as well as within their contested fields of inquiry" (Burawoy, 2021b:255).

The basic premise of a dialogue has pride of place in Burawoy's articulation of a reflexive social science. Burawoy (2005) has previously identified Du Bois as an exemplar of public sociology. Echoing Du Bois, Burawoy describes public sociology as a "double conversation" as sociologists enter into dialogues with publics already in dialogue with one another. While Du Bois clearly personifies the best of public sociology, my suspicion is that Burawoy's deep interest in Du Bois turns on the recognition of a missed encounter with Du Bois in Burawoy's writings on the extended case method. His defense of this methodology, introduced in 1998, uses a series of dialogues - between observers and participants, the micro and the macro, and between theories - to make sense of the social world. With the privilege of hindsight, Burawoy is in conversation with Du Bois, even if Du Bois is never mentioned in the 1998 methodological essay. These dialogues reveal shared imperial intimacies.

Burawoy first develops the extended case method in his study of Zambian copper mines in the late 1960s, in the wake of Zambian independence in 1964 (a year after the death of Du Bois). Through deep immersion in the Copperbelt, Burawoy found that white managers were able to secure a "color bar" that mirrored the racial and class stratification of Zambia's 
workforce during British rule. In the African context the notion of a color bar is derived from the 1911 Mines and Works Act (known also as the "Colour Bar Act"), legislation in South Africa which helped set the stage for apartheid. But it is used generally as a historically specific variation of Du Bois's color line, encapsulating those formal and informal practices of racial discrimination in Britain and in British colonies. ${ }^{8}$ Yet "color bar" would enter Du Bois's writings and speeches in important ways as his Pan-African politics developed through the early $20^{\text {th }}$ century. Du Bois will include Rhodesia in his statement, in "The Souls of White Folk," of how the dark colonies "belt the earth" (1999[1920]:26). This essay is included in his book Darkwater (which, perhaps not coincidentally, Burawoy has professed to me is his favorite book of Du Bois's). In the essay "The Hands of Ethiopia" in Darkwater, Du Bois will link the "brown and yellow" anticolonial struggles "against the color bar" (1999[1920]:33). Following the first three convenings of the Pan-African Congress between 1919 and 1923, as well as his first trip to Africa in 1923, Du Bois will take a special interest in the very color bar (in the context of the Zambian Copperbelt) that would command Burawoy's attention four decades later. In 1925, Du Bois corresponded with Morris Alexander, a Jewish member of the South African Parliament, concerning a bill that would amend the Mines and Works Act. ${ }^{9}$ In his 1944 autobiographical essay, “My Evolving Program for Negro Program,” Du Bois will again articulate the color bar in the context of his Pan-African philosophy; but the term will elevate in importance in Du Bois's mind as he will use it to rearticulate his intimate childhood memories of developing his sense of double consciousness. ${ }^{10}$

In graduate school, my developing feminist consciousness found in the extended case method a harmonious way of thinking about power and history. I used this ongoing dialogue between feminism and reflexive science to think through my own standpoint as a researcher. Yet 
in completing research for my book (Blume Oeur, 2018), I never provided a sufficient response to the question: What claim do I have, as someone who is not African American, to study the lives of African American youth? But I have learned to situate this question (and myself) in nested historical relations: indeed, imperial intimacies. I now ask, guided by the critical work of Tang (2015): What forms of racial consciousness have I, a child of poor Cambodian refugees, developed given the historical reality of Cambodian resettlement in American hyperghettos, the marker of Black captivity in the aftermath of slavery? How might these intimate connexions reveal the unfinished work of American colonialism in Southeast Asia? And how might the answers to these questions shape my professional and political obligations as someone writing on anti-Blackness, the legacies of slavery, and decolonization?

A synergy of Marx and Fanon will help Burawoy in his study of the color bar, capital, and labor in postcolonial Africa; but I am curious how Burawoy would reassess his findings now through a Du Boisian prism. And in his 1998 essay on the extended case method, we hear very little about the observer in the first dialogue between observer and his participants in Zambia. Burawoy explains that his identity was a barrier to understanding the psyche of Zambian workers and that it would inhibit (the otherwise flawed goal of) replicating his study. So, I would also ask of Burawoy: what obligations does a white, British sociologist who once studied a former British protectorate have in the present dialogues on decolonization?

\section{Burawoy Meets Du Bois}

A conversation between Burawoy and Du Bois would, I hope, help develop a decolonial method that embraces reflexivity, rigorous critique, and creativity and disobedience. As facilitator, I would urge them to think through the feminist politics of such a method and how 
these politics sharpen their respective anti-capitalist aims. Burawoy (2005:15) writes that a public sociology was born when "the civil rights movement... transformed sociologists" understanding of politics" and "it was the feminist movement that gave new direction to so many spheres of sociology." By giving priority, however subtle, to the color bar, Burawoy echoes the sentiment of Du Bois (1999[1920]:105), who wrote that "the uplift of women is, next to the problem of the color line and the peace movement, our greatest modern cause.” Feminist scholars have noted Du Bois's tendency here to juxtapose feminism with anti-racism, without ever completely integrating the two. While Du Bois agitated for the rights of Black women and gender equality, he also diminished the intellectual contributions of Black women (Gillman and Weinbaum, 2007). The history of silencing Black women's intellectual contributions is an act of symbolic violence and mirrors the same accusation Burawoy (2019) makes of Bourdieu, whose misogynist practices silenced the contributions of Simone de Beauvoir.

While Burawoy describes an encounter between Du Bois and Weber as contentious, they had one important thing in common: their wives, Shirley Graham Du Bois (1971) and Marianne Weber (2009[1926]), themselves outstanding intellectuals, wrote biographies of their husbands and cared for them while they were sick. This unacknowledged labor helped preserve their legacies and inform the very dialogues we create between these leading men today. In her 1971 biography, Graham Du Bois — who helped guide her husband's sharper turn to the Left—fought to acknowledge Du Bois's anticolonial efforts precisely when he had become the "scholar exiled," as Burawoy calls Du Bois. This history was a necessary corrective to the first biographies Du Bois (e.g., Broderick, 1959), published before his death, which are tainted by Cold War-era skepticism of Du Bois's radical politics. And Du Bois would sustain dialoguestroubling, perplexing, critical, and insightful—with women characters in his fiction writing. The 
most extraordinary character in The Black Flame is Jean Du Bignon, a sociologist and assistant to Manuel Mansart, the president of a Negro College in the South. She reads C.L.R. James's classic The Black Jacobins and shares Du Bois's anticolonial freedom dreams.

A critical feminism casts light on the penumbral locations where the political meets the personal. It thinks beyond outward-facing politics to the more private, dimly lit legacies of empire. While Burawoy considers how the ideas of the early Du Bois resonate with the conclusions in Durkheim's book The Division of Labor in Society, a feminist method here urges reflection on the personal relations of these two theorists. What might it mean, for example, that Durkheim found himself at a loss to apply his own theories to the study of war and morality following the death of his son, André (Abbott, 2019), a soldier who died in World War I defending the very French empire that Du Bois would later critique? These are not simply intellectuals or activists who dialogue with one another. They were also fathers whose social visions were shaped by the experience of losing children at the height of global empire, the crucible from which emerged the discipline of sociology in Europe and the United States (Connell, 1997). Du Bois's son, Burghardt, succumbed in 1899 to diphtheria, a disease that today continues to disproportionately kill children in the Global South and former colonies (Blume Oeur 2021).

\section{Conclusion}

Michael Burawoy was a guest speaker in a 2005 course I took my first year of graduate school. He said something that I now tell my own students: theories are like maps that guide you when you seek direction in a labyrinthine social world. But maps have also been the fantasies of cartographer-imperialists, and their attendant desires for discovery and progress. Efforts to 
decolonize Sociology should think carefully about the discipline's methods and maps. How does one draw a map "without the mandate for conquest" (Morrison 1993:2)? We ought to be aware of the ghosts that haunt Sociology's own vocabulary as we reimagine new ways of dialoguing with one another. And sociologists should look outside our own discipline for help in facilitating these conversations. Recomposing a discipline's foundations should not lead to more disciplinary provincialism.

The many shadows over Du Bois's work would take a most provocative form in his 1940 memoir Dusk of Dawn. Du Bois (2007[1940]:73) writes that he is "the child of twilight," finding in the shadows not simply a place of oppression but a life of dignity and resistance (guided by the moonlight, as he writes). But as is common practice for Du Bois, he stresses the antinomies of "twilight," as he later refers to the unconscious and irrational character of race prejudice as "the twilight zone." I want to highlight another interpretation, one that is consistent with the utopian (but still pragmatic) Du Bois that Burawoy embraces in his essay. Twilight is a partial occlusion, a penumbral location, a shadowplay between daylight and darkness. It is an opportunity. For the whole debate over Du Bois and the canon matters most if whatever dialogues that emerge can help us navigate today's crises, themselves shaped by the legacies of colonialism. I imagine Burawoy is speculating about the possibility of such dialogues to produce coalitions, or the "myriads of nodes" among groups and communities, and publics and intellectuals, he has written about previously (Burawoy, 2005:25). We move finally from dialogue as a conversation to its essential promise of connection and relation. Intellectual dialogues are insular, but dialogues in their many forms - deliberations, town hall meetings, partnerships — and their related catchphrases ("talking it out," "finding common ground," "learning to listen") are unavoidable today and widely viewed as necessary for creating 
relationships that will promote "civic repair" (Polletta, 2020:3). The stakes are high, and the future is indeterminate. As Morrison (1988:163) remarks, "all necks are on the line."

And Burawoy urges us to turn to Du Bois because the survival of humanity itself is on the line. If that is the case, we might as well bring our necks - and heads and hearts - together. Following de Leon (2019), Du Bois's lesson for our current conjuncture is to embrace not only better ways of mobilizing politically, but also an ethic of love ${ }^{11}$; an "erotic politics," as King (2019:209) has offered, for the "new worlds we desire and make for one another."

Transformative intellectual dialogues require hard work and accountability, but they think intimately and nourish those radical friendships that imagine new possibilities collectively. Let's reconstruct our dialogues together.

\section{Acknowledgements}

An earlier version of this essay was presented at the "Decolonizing Sociological Theory and Knowledge" symposium at Brown University in Providence, RI, in October 2021. Comments shared by many participants at that day-long event helped tremendously as I revised this essay, and I thank Rory Kramer especially for his generous feedback.

\section{Notes}

${ }^{1}$ Burawoy elsewhere (2021b) discusses the potential to revolutionize the canon with the inclusion of Du Bois through a dialogue with Connell (1997). For Burawoy, "reformist" fails to capture this revolutionary potential.

${ }^{2}$ With all apologies to Morrison, I am adopting for the title of my article a phrase-_"canon fodder"- that was the original but ultimately scrapped title of her 1988 lecture. 
${ }^{3}$ To be sure, with this statement Morrison expresses caution because she believes African American literature is often interpreted reductively when it is viewed as a window (or door) into scientific truths. But I am concerned more with how Du Bois views an intimate dialogue between fiction and (non-fiction) science.

${ }^{4}$ To apply Lowe's (2015) observations, themselves rooted in the work of Raymond Williams, the invocation of Du Bois has been a slow "emergent" formation in Burawoy's Marxist intellectual biography. Once more with Williams: I am curious about the structures of feeling in Burawoy's work that motivate him to restructure the canon.

${ }^{5}$ Du Bois himself would stage encounters with imaginary interlocutors, as he did in Dusk of Dawn (2007[1940]).

${ }^{6}$ As Mullen (2015:127) writes, the trilogy demonstrates "Du Bois's long march toward support, understanding, and misunderstanding of the Chinese Revolution, of Japan's place in twentiethcentury history, and of his own twilight relationship to Marxism and the world revolution concept."

${ }^{7}$ As Mullen and Watson (2005) note, Du Bois's early, narrow vision of imperialism was shaped by a romanticized view of Japanese culture corrupted by Western morality.

${ }^{8}$ For this reason, Du Bois will also reference a color bar in relation to the British empire in India. I thank Phillip Luke Sinitiere for this insight.

${ }^{9}$ Several letters were exchanged; see, for example, Du Bois, W.E.B., 1868-1963. Letter from W.E.B. Du Bois to Morris Alexander, July 31, 1925. W.E.B. Du Bois Papers (MS 312). Special Collections and University Archives, University of Massachusetts, Amherst Libraries. Available at: https://credo.library.umass.edu/view/full/mums312-b027-i211. 
${ }^{10}$ As Du Bois writes, "The secret of life and the loosing of the color bar, then, lay in excellence, in accomplishment... There was no real discrimination on account of color-it was all a matter of ability and hard work." He then admits that his fierce determination "doubtless cloaked some half-conscious misgivings" about whether hard work alone could dissolve the color bar.

${ }^{11}$ de Leon shared these reflections in his plenary address at the Second Convening of the Du Boisian Scholar Network at Brown University in May 2019.

\section{References}

Abbott A (2019) Living one's theories: Moral consistency in the life of Émile Durkheim. Sociological Theory 37(1): 1-34.

Andrews S (2007) Toward a synaesthetics of soul: W.E.B. Du Bois and the teleology of race. In: Keller M and Fontenot CJ (eds) Re-Cognizing WEB Du Bois in the Twenty-First Century: Essays on W.E.B Du Bois. Macon, GA: Mercer University Press, pp. 142-185.

Berman N (2000) Shadows: Du Bois and the colonial prospect, 1925. Villanova Law Review 45: 959-970.

Blume Oeur F (2021) Fever dreams: W.E.B. Du Bois and the racial trauma of COVID-19 and lynching. Ethnic and Racial Studies 44(5): 735-745.

Blume Oeur F (2018) Black Boys Apart: Racial Uplift and Respectability in All-Male Public Schools. Minneapolis: University of Minnesota Press.

Broderick FL (1959) W.E.B. Du Bois: Negro Leader in a Time of Crisis. Stanford, CA: Stanford University Press.

Burawoy M (2021a) Decolonizing sociology: The significance of W.E.B. Du Bois. Critical Sociology 47(4-5): 545-554. 
Burawoy M (2021b) Why is classical theory classical? Theorizing the canon and canonizing Du Bois. Journal of Classical Sociology 21(3-4): 245-259.

Burawoy M (2019) Symbolic Violence: Conversations with Bourdieu. Durham, NC: Duke University Press.

Burawoy M (2005) For public sociology. American Sociological Review 70(1): 4-28.

Carby H (2019) Imperial Intimacies: A Tale of Two Islands. New York: Verso.

Connell RW (1997). Why is classical theory classical? American Journal of Sociology 102(6): $1511-1557$.

de Leon C (2019). The tactics of mobilization, the ethics of care. 5 May. The Du Boisian Scholar Network National Convening. Brown University, Providence, RI.

Du Bois WEB (2007[1961]). The Black Flame Trilogy: Worlds of Color. New York: Oxford University Press.

Du Bois WEB (2007[1940]) Dusk of Dawn: An Essay Toward an Autobiography of a Race Concept. New York: Oxford University Press.

Du Bois WEB (1999[1920]) Darkwater: Voices from Within the Veil. Mineola, NY: Dover. Du Bois WEB (1992[1935]) Black Reconstruction in America: 1860-1880. New York: Free Press.

Du Bois WEB (1990[1944]) My evolving program for Negro freedom. Clinical Sociology Review 8(1): 27-57.

Du Bois WEB (1961) Africa and the French Revolution. New York: Freedomways. Fields KE (2002) Individuality and the intellectuals: An imaginary conversation between W.E.B. Du Bois and Emile Durkheim. Theory and Society 31(4): 435-462. 
Filmer P (2003) Structures of feeling and socio-cultural formations: The significance of literature and experience to Raymond Williams's sociology of culture. The British Journal of Sociology 54(2): 199-219.

Gillman S and Weinbaum A (eds) (2007) Next to the Color Line: Gender, Sexuality, and W.E.B. Du Bois. Minneapolis: University of Minnesota Press.

Itzigsohn J and Brown KL (2020) The Sociology of W.E.B. Du Bois: Racialized Modernity and the Global Color Line. NYU Press, New York.

Kennedy MD (2019) National cultures and racial formations: Articulating the knowledge cultures of Kłoskowska and Du Bois. Kultura i Społeczeństwo 63(3): 7-30.

King TL (2019) The Black Shoals: Offshore Formations of Black and Native Studies. Durham, NC: Duke University Press.

Krell DF (2000) The bodies of Black folk: From Kant and Hegel to Du Bois and Baldwin. boundary 2 27(3): 103-134.

Lemert C (2000) The race of time: Du Bois and Reconstruction. boundary 2 27(3): 215-248.

Lowe L (2015) The Intimacies of Four Continents. Durham, NC: Duke University Press.

McAuley CA (2019) The Spirit vs. the Souls: Max Weber, W.E.B. Du Bois, and the Politics of Scholarship. Notre Dame, IN: University of Notre Dame Press.

McKittrick K (2021) Dear Science: And Other Stories. Durham, NC: Duke University Press. Meghji A (2021) Decolonizing Sociology: An Introduction. London: Polity.

Morris A (2015) The Scholar Denied: W.E.B. Du Bois and the Birth of Modern Sociology. Oakland: University of California Press.

Morrison T (1993) Playing in the Dark: Whiteness and the Literary Imagination. New York: Vintage, New York. 
Morrison T (1988) Unspeakable things unspoken: The Afro-American presence in American literature. 7 October. The Tanner Lectures in Human Values. The University of Michigan, Ann Arbor.

Mullen B (2015) Un-American: W.E.B. Du Bois and The Century of World Revolution.

Philadelphia, PA: Temple University Press.

Mullen B and Watson C. (eds) 2005. W.E.B. Du Bois on Asia: Crossing the World Color Line. Jackson: University Press of Mississippi.

Polletta F (2020) Inventing the Ties That Bind: Imagined Relationships in Moral and Political Life. Chicago, IL: University of Chicago Press.

Riley D (2021) Notes on the Curriculum. In Sidecar. Available at: https://newleftreview.org/sidecar/posts/notes-on-the-curriculum (accessed 23 December 2021).

Sáenz CM (2015) An “Other” Feminism: Sharing Zapatista Women’s Stories. In Truthout. Available at: https://truthout.org/articles/an-other-feminism-a-review-of-hilary-klein-scompaneras-zapatista-women-s-stories (accessed 4 December 2021).

Steinmetz G (2013). Sociology and Empire: The Imperial Entanglements of a Discipline. Durham, NC: Duke University Press.

Tang E (2015) Unsettled: Cambodian Refugees in the NYC Hyperghetto. Philadelphia, PA: Temple University Press.

Taylor P (2004). What's the use of calling Du Bois a pragmatist? Metaphilosophy 35(1/2): 99114.

Weber M (2009[1926]). Max Weber: A Biography. Trans. Zohn H. New Brunswick, NJ: Transaction. 
Weinbaum AE (2013) Gendering the general strike: W.E.B. Du Bois's Black Reconstruction and Black feminism's “propaganda of history.” South Atlantic Quarterly 112(3): 437-463. Williams R (1980) Problems in Materialism and Culture: Selected Essays. London: Verso.

\section{For correspondence}

Freeden Blume Oeur, Department of Sociology, Tufts University, Eaton Hall, Medford, MA 02155, USA. Email: freeden.blumeoeur@tufts.edu. 